Library Acquisitions: Practice \& Theory, Vol. 21, No. 1, pp. 19-27, 1997

Copyright (C) 1997 Elsevier Science Ltd

http://www.elsevier.com/wps/find/journaldescription.cws_home/293/description\#description

\title{
License Agreements in Lieu of Copyright: Are We Signing Away Our Rights?
}

\section{Trisha L. Davis}

Head, Continuation Acquisition Division

The Ohio State University Libraries

1858 Neil Avenue Mall Columbus Ohio 43210-1286

Abstract - For libraries, the shift from ownership of printed works to access of electronic works has required the negotiation and processing of license agreements. Many rights and restrictions covered in license agreements are in direct conflict with traditional library processes and procedures. These agreements are contracts, based on contract law, and as such often supersede standard library policy based on copyright law. A comparison of rights guaranteed by the copyright law and rights assigned by a selected set of license agreements identifies certain areas of user rights that must be identified and protected. Copyright (C) 1997 Elsevier Science Ltd

\section{INTRODUCTION}

Libraries traditionally have relied on interpretations of the copyright law to advise them of any limitations on user rights. For decades, library policies were based on the copyright laws of 1909, which allowed free use of materials to all users. Only copying rights were limited and that practice was not a significant issue until the advent of photocopiers in the workplace in the 1950s. The Copyright Revision Act of 1976 was conceived to answer new questions about copying and author's rights related to the proliferation of multimedia formats and advanced copying technologies. As soon as the 1976 Act took effect in 1978, however, it was simply inadequate.

What no one could predict in 1978 was the inability of the copyright law to address the rapidly expanding electronic technologies. As authors and publishers became apprehensive about protection of their intellectual property, they lost faith in copyright protection and turned to contract law to defend their rights. Rather than sell a copy of the product to libraries, they chose to license the use of the product. They moved beyond copyright protection when they defined and limited users' rights through contract law.

For all types of libraries, the shift to licensing raises many difficult questions. Each library must deal with interpreting the terms of license agreements and understanding how they apply to their intended use of the product. The involvement of acquisition, reference and automation staff throughout the process is required to handle the complexities of selection, purchase, and system application options. Decisions on method of access, use capabilities, and user restrictions must be reached before a final purchase decision can be made. To handle these challenges effectively, librarians must understand how copyright and contract law differ and determine the issues most relevant to their library's application. 
In order to provide a standard guide to determining user rights, the author investigated both the copyright law and the basic content of license agreements. An analysis and comparison of five standard license agreements [1] identified significant areas of conflict with standard library practices based on copyright law. A review of the literature on copyright and its many ongoing interpretations reveals that the law is inadequate to address these various issues. Yet this review and analysis answered many questions about copyright and underlined the significant areas of conflict between copyrights and lease rights. The following questions and answers summarize the results of the study.

\section{WHAT IS COPYRIGHT?}

Any way it is explained, copyright is a complex concept. The U.S. Congress has been struggling to define copyright since the first U.S. copyright act was passed in 1790 . The basic purpose of copyright is to assure individual authors and creators of literary, musical, and artistic works the exclusive rights to their creations. Whoever owns the copyright to a work may copy and distribute that work as they wish, usually for some form of economic reward. Until the midtwentieth century, copyright was an issue between the author and the publisher alone. The author shared the copyright with the publisher who had the resources to copy, distribute, and sell the work for the author. Based on this simplistic concept, the Copyright Act of 1909 provided adequate protection for more than sixty years. With the advent of photocopy and other electronic technologies, however, the protection of individual works became a complex challenge to define.

The Copyright Revision Act of 1976 is well known to the educational, publishing, and library communities. This revision was conceived to deal specifically with changing technologies. It addresses the issues of reproducing copyrighted works in any format, preparing derivative works, distributing for sale or lease, and publicly performing or displaying. Although the 1976 Act was written in collaboration with computing, media, information, and educational specialists, many sections provide guidance only in general and often vague terms. Until the ambiguities are challenged in court, the Law has proven inadequate for rulings in the rapidly evolving electronic environment.

\section{WHAT IS THE “FAIR USE” DOCTRINE?}

To assure public access to information, Congress included a fair use doctrine in the 1976 Act. This concept was designed to protect the authors' rights while allowing limited infringement of the law for personal use. Section 107, known as the fair use provision, allows someone to use a copyrighted work without the copyright owner's permission in a few, selected instances.

Fair use is never explicitly defined in the 1976 Act. The provision provides instead for general criteria that are meant to be applied to each specific instance to determine whether that use of the copyrighted work constitutes fair use. These criteria include the purpose and character of the use, the nature of the work, the amount of the total work to be used, and the effect of that use on the market value. The intent is to allow limited use of copyrighted works for purposes such as teaching, news reporting, criticism, and research [2]. According to Thomas Hemnes and Alexander Pyle, lawyers specializing in copyright law and intellectual property rights, "The issue of what constitutes fair use has been called the most troublesome in the whole law of copyright" [3]. 


\section{HOW DOES THE 1976 COPYRIGHT REVISION ACT APPLY TO ELECTRONIC PRODUCTS?}

Before the 1976 revision was completed, Congress realized they had not finished their task. They set up a separate commission, The National Commission on New Technological Uses of Copyrighted Works (CONTU), to handle copyright questions about information stored and transferred in electronic format. In 1978, the final CONTU recommendations allowed electronic data to be copyrighted and protected in the same manner as an individual author's works. Thus the doctrine of fair use applies to electronic works, as well. As with printed works, the specific content, facts, and ideas are not protected, but their particular form of expression can be copyrighted.

\section{WHY IS THIS NOT ENOUGH?}

Problems quickly arose for authors, publishers, and librarians as the technological advances of the last decade made copying massive amounts of software and data from CDs or diskettes too easy to resist. Large-scale downloading and third-party usage of copyrighted software and information became a regular occurrence. The same users, who understood and normally respected copyright limitations when making photocopies, began to ignore restrictions on electronic copying. The publishers and distributors were unable to maintain control of the constantly evolving electronic technologies. This made compensation to authors difficult and expensive because piracy was accomplished so easily and was so difficult to trace [4].

In response to the uncertainty of copyright law and its failure to protect their investments, publishers turned to contract law. Rather than sell a copy of a work and depend on the copyright laws for protection and remuneration, they began to offer only a license agreement to use the work. The purchaser acquired only the right to use the data or information as defined in the license agreement. The first licenses appeared attached to computer disks containing software. These were commonly referred to as "shrink-wrap" licenses because they were printed on or attached to the packaging around the disk. With the advent of CD-ROM databases in the early 1990s, publishers turned to more formal license agreements requiring signature by both parties. The appearance of contracts left little doubt that whatever rights were guaranteed by federal, state, and local laws, signing the contract eliminated them.

\section{HOW DOES THIS SHIFT TO LICENSE AGREEMENTS AFFECT LIBRARIES?}

Libraries traditionally have assumed full user rights to works and information within their collections. Until the advent of licensing, authors and publishers rarely questioned who the library user would be or where, how often, and for what purposes their work would be used. Libraries acquired materials, stored them wherever they pleased, made them available to any user, and worried mostly about photocopying abuses and preservation issues.

After the 1976 Act, libraries began to notice licenses when they acquired audiovisual materials and computer software. These first licenses were passive agreements often printed directly on the product or shrink-wrapped to the packaging. Such agreements declared that the user accepted the terms of the license as soon as the product was opened for use. Most libraries were aware of these agreements and realized their use rights were somewhat limited. Yet, as with traditional print materials, they owned a copy of the work. Their concerns were limited to paying royalty fees for showings of films and videos or copyright abuse at the photocopier. Librarians believed their use rights were still governed primarily by the fair use provisions of the copyright law. 
Librarians first became concerned about user rights when license agreements requiring signature began to appear more frequently. Some of these agreements contradicted what the librarians assumed were basic user rights. The specific requirements of access, precise user definitions, and restricted networking options in many agreements limited their traditional library applications. Many questions were raised, yet many licenses were signed in ignorance. Librarians and publishers alike became worried about the consequences.

\section{WHAT EXACTLY ARE LICENSE AGREEMENTS?}

A license agreement is a form of legal contract between two or more parties in which a licensor allows certain use rights of a product to a licensee, normally for a fee. A common example is the lease of a car in lieu of purchase. The licensee pays to possess and use the car for an established period of time. At the end of the license period, the licensee must return the car to the owner, the licensor. The contract may include other requirements such as a limit on the number of miles driven, required maintenance, responsibility for any damages sustained, and penalties for not meeting the terms of the contract.

For libraries, a typical example is a license agreement offered for the lease of an electronic database. The licensee pays for the rights to use the database, not the ownership of the intellectual property contained nor the software needed to access the data. In some instances, the license transfers ownership of the medium on which the data is recorded, such as a computer tape or CD-ROM. However, many contracts require the return of the database, any copies made, and all related materials at the end of the subscription period. In these instances, the library as licensee owns nothing. The licensor retains full ownership of the intellectual and the physical property.

Today, most librarians understand that a license agreement is a legally binding form of contract. They recognize licenses when they find them and remain alert for licenses that appear unannounced. It remains very important to look for passive licenses, even though their validity has not been tested in court. As mentioned above, passive licenses may be printed within the packaging or shrink-wrapped to part of the product. Some passive licenses are not even available until the product is mounted for use and the license screen displays. License agreements requiring signature also appear in all shapes and sizes. Sometimes the format of a license looks similar to an order or a subscription renewal form. Only the small print will reveal that by signing, the library is agreeing to terms of a license.

\section{HOW DO LICENSE AGREEMENTS RELATE TO COPYRIGHT?}

License agreements are governed by contract law, not copyright law. Once accepted, either by formal signature or passive acknowledgment, fair use options and other rights assured by the copyright law are superseded by the terms of the contract. The library will not own the copy, so user rights are identified solely by the license agreement. Any contractual definitions, capabilities, responsibilities, or obligations within the contract supersede any other agreements, common law, state law, and even federal law, including fair use rights. A typical ownership statement appears in the Chemical Abstract Service agreement:

The CAS CD-ROM product is and shall remain the proprietary property of the ACS.... The copyright and title to all property interests in or to the ACS database is in and shall remain with ACS as owner and this Agreement does not grant any 
right of ownership in the ACS database. You have no rights to the data and its use except as set forth in this Agreement.

\section{WHAT ADDITIONAL RESPONSIBILITES ARE RECOMMENDED FOR HANDLING LICENSE AGREEMENTS?}

The first step is to identify the contract and determine how it will impact the library. A passive license for a stand-alone database to be mounted permanently on a workstation in the Reference Room will not pose many problems. On the other hand, a license for a networked product that will be accessible from remote sites and made available for up to twelve simultaneous users may require significant editing.

The next step is to review the license agreement and identify the basic sections. There is no accepted standard format, order of content, or even labeling of elements within contracts. They are constructed to the specifications of the licensor. Most licenses will include certain basic elements that relate to the library's rights and limitations. The areas of particular concern to libraries are user definitions, use capabilities, and contractual obligations.

Finally, each element of the license agreement must be understood and interpreted in light of the library's needs. As with any legal contract, if the agreement is too restrictive, it should be negotiated and changed as necessary for signature. A signed license agreement, in particular, obligates both parties to the terms of the contract. No librarian ever should accept or sign a license agreement unless authorized to do so by the appropriate authorities in the organization.

\section{WHAT SHOULD THE LIBRARIAN LOOK FOR WHEN EXAMINING A LICENSE AGREEMENT?}

A typical license agreement contains certain standard elements. Most contracts begin with a series of definitions: the purpose of the license, the parties to the contract, and the products involved. These sections may be very brief and general or extremely detailed. Of all the contracts analyzed, the Chemical Abstracts Service agreement included the most precise and straightforward definitions section:

The American Chemical Society ("ACS") acting through its Chemical Abstracts Service division ("CAS" or "LICENSOR") hereby grants... ("the Licensee") a non-exclusive, nontransferable license to use the 12th Collective Index on CDROM ("CAS CD-ROM Product") solely in accordance with the terms of this Agreement.

The next element is normally a statement of license rights, or permitted uses. This section is normally brief and to the point. There may also be statements to the effect that the licensee's rights are subject to restrictions found elsewhere in the agreement. At some point, most licenses also state that any rights not expressly covered by the agreement are reserved to the licensor. The SilverPlatter agreement state this succinctly:

All rights not expressly granted to the Customer herein are reserved to SilverPlatter..." 
The section on use restrictions is normally quite extensive and may include multiple elements that may or may not apply to their specific lease. For example, many contracts include separate sections for single users and for network applications. General restrictions on activities such as reselling the product, decompiling the software, or copying the database are common and should not be of concern. However, specific reference to how, when, by whom, and for what purpose the product may be used must be analyzed carefully.

A variety of license and product-specific sections are included after the user rights and restrictions. The licensor's explicit statement of ownership and copyright should be located and examined for clarity. Many contracts typically advise that illegal copying, transfer, or use may be a civil or criminal offense. The DIALOG agreement states explicitly such a warning:

The Products, including all portions thereof, except where expressly stated otherwise, are protected by copyright and other laws respecting proprietary rights. Unauthorized reproductions, transfer and/or use may be a violation of criminal as well as civil law.

Any sections referring to training, user support, product updates, and replacement discs should be examined thoroughly. The library should never assume that any related product or service will be provided. If the product or service is not explicitly defined in the license, it should be appended to the contract and agreed upon by the licensor well in advance of accepting or signing the agreement.

As electronic publishers have gained expertise in the creation and use of license agreements, many are including specific obligations on the part of the licensee within the contract. At first glance, these sections are not as obvious as those detailing their ownership rights and use restrictions. Hidden within paragraphs about fees, payments, and returns are additional costs for late payments, liability for the costs of collections, and fines for not returning products by the due date or via the proper carrier. The library should be alert to sections defining support or requiring action to nonspecific terms, such as "user materials," "nonstandard distribution charges," "applicable fees," notification in writing, or any reference to action at the licensor's discretion. Unless more specific terms are negotiated, the library may be obligated to unacceptable charges or required to pay additional charged for expected services.

Finally, the remaining portions of the agreement describe contractual issues that can be quite difficult to understand for the lay person. Most licenses include a series of sections describing warranties, liabilities, indemnification, termination rights, force majeure, governing law, and other general provisions. In the five agreements analyzed, these sections are printed in boldface or uppercase for emphasis. While some of these elements seem to be totally unacceptable, much of what appears is standard contract language and not negotiable. No publisher or licensor will warranty the accuracy, completeness, comprehensiveness, or even functionality of the product, the intellectual content, or the accompanying documentation. Such elements should be approved or edited by someone with experience handling contracts.

\section{WHY IS USER DEFINITION SUCH AN IMPORTANT ISSUE?}

When publishers simply sold books and journals to libraries, they never questioned who the end user would be. Any person allowed into the library could access the book, copy from it, and reuse the information for any purpose. The library was never held responsible for user behavior. Electronic publishers, however, require specific detail on types of users and the 
number of users. They fear widespread abuse of their products due to the ease of copying and transmission. The copyright owner wishes to limit the use of the product by having sole control over who uses it. This is the primary purpose for shifting from copyright protection to contract law.

Licenses that restrict access to certain categories of users are the most difficult to handle. The library must decide how it wishes to define its users, pay the appropriate fees, and then limit use to those categories. For instance, user definitions for academic institutions normally include faculty, staff, and currently enrolled students. The user group definition of the UMI ProQuest subscription license is sufficiently generous to please most libraries.

... if licensee is a public library, educational institution, governmental agency or non-profit institution allowing free public access to data and information, then, subject to any restrictions of the copyright owner, Licensee may provide public access to and retrieval of data and information by or for public users.

Many contracts, however, fail to address part-time employees or students, users at branch campuses, outside researchers and contractors working on campus, and special classes of library users such as alumni, local educators, or volunteers. Many public libraries cannot define their users beyond the basic information required of any registered patron. Some special libraries have very unique categories of users that may be defined by type of work, content of work, or hierarchical relationship within the company. To be assured all users are included, many libraries create their own definitions of users and append it to the license. The DIALOG OnDisc agreement includes an entire section devoted to defining "Third-Party Access." They allow access and full user rights to traditional patron classes of public, educational, government, and other nonprofit libraries, but no access rights are available to any for-profit entities.

Customer may provide public access to and retrieval from the Database by or for public users. No other transfer of Database portions are permitted under this Agreement and no rights are granted permitting any systematic retrieval and printing of Database portions to third parties by or through any for-profit entity.

Defining the number of users within the contract parameters can be equally complex. The basic CD-ROM license usually is written for a single user at a single workstation. However, if the database is accessed via a local area network, rather than mounted at the workstation, the definition changes. To the licensor, this is a single user network, in which only one person at a time may use the product, but access is available from any workstation on the network. For many products, a single user may not have access via a network unless an additional network license fee is paid. This model often is extended to a multiuser network in which a limited number of simultaneous users may access the product from any workstation on the network. Most libraries are forced to limit the number of simultaneous users only when system overuse dramatically slows response time, networking fees become unaffordable or unreasonable, or the publisher simply sets a limit.

The SilverPlatter license agreement defines both Multi User Rights and Multi User Restrictions. 
For purposes of this clause a person is affiliated with the customer if he or she is an employee of the Customer or (if the Customer is an educational institution) a registered patron of the Customer. The Database, Software, CD-ROM disc, diskettes, and printed materials provided hereunder to the Customer may be used only by the Customer personally, or if the Customer is an organization, only internally within that organization by up to the number of simultaneous users for which the Customer has paid SilverPlatter its appropriate network fee.

The DIALOG agreement allows use only on a single workstation unless a LAN license agreement is signed. As a LAN license, there is no limit on number of users, but additional fees must be paid for remote users.

Access to DIALOG OnDisc Products via your institution's LAN is limited only to employees or members of your institution.

\section{WHY ARE THERE SO MANY OTHER USE RESTRICTIONS?}

The copyright laws simply do not address today's many methods for electronic copying. To protect their rights, most licensors state explicitly what may and what may not be done with the product. Licensed rights are most clearly stated in the SilverPlatter agreement:

Subject to the restrictions... below, the Customer is hereby granted a nonexclusive license to: a) make searches of the Database; b) make one or more copies of any search output in hard copy form, which may be utilized by the Customer but may not be sold; c) make one copy of any search output in electronic form--i.e., diskette, hard disk, or tape--to be used for editing or temporary storage only; and d) make one copy of the software diskette and documentation, for archival purposes only.

This well-written description of approved uses appeared only in the SilverPlatter contract. Most license agreements include a series of clauses outlining uses that are forbidden. Under a section labeled Restrictions on Use, the Reed Reference agreement simply states that:

Reed Reference Publishing is granting to you a non-exclusive, non-transferable license to use the database and the software program in accordance with the terms of this license agreement. The remainder of the section outlines what You may not do.

In order to protect their intellectual property, the owners and licensors set out many restrictions on activities most libraries and library users would never understand. These restrictions vary widely from contract to contract, but similar topics arise: printing, downloading, electronic transmission, modification of the software, transfer of license, sale of the data, etc. The Chemical Abstract Service agreement outlines most succinctly what is not allowed. The following examples leave no room for misinterpretation:

Licensee may make only one copy of the software contained in the CAD CDROM Product for backup purposes only. Licensee's copying or other recording of 
portions of the CAD CD-ROM Product that is for the purpose of, or has the effect of, avoiding payment to CAS of additional fees under this Agreement shall be considered a breach of this Agreement by Licensee. Dial-In Access to the CAD CD-ROM Product is not permitted under any circumstance.

Even more restrictive wording appears in the DIALOG agreement:

Portions of the Database may not be copied onto electronic/magnetic media (or other machine-readable form) except for temporary use or storage in conjunction with Customer's editing or reformatting of data for purposes of making a single print-out (human-readable copy) thereof.

More common generic clauses appear in the UMI ProQuest agreement:

... Licensee will not copy, duplicate, transfer, transmit, lease or sell, decompile or reverse engineer, in whole or in part, the licensed products and will not exploit the Licensed Products commercially in any manner, without UMI's express proper written authorization.

\section{WHAT OTHER TYPES OF CONTRACTUAL OBLIGATIONS TYPICALLY ARISE?}

As license agreements have become more product-specific, some licensors have included requirements for standard business operations within the contract. No traditional publisher or library vendor ever asked a library to sign a legally-binding contract to assure payment within thirty days. Libraries always have maintained their business relationships on trust and experience. Yet, many license agreements ask the user to agree formally to specific obligations and outline consequences, such as fines or loss of license, if these obligations are not met. A typical example appears in the DIALOG agreement:

DIALOG invoices are due upon receipt and will be deemed delinquent if not fully paid within thirty (30) days thereafter. Delinquent invoices are subject to interest charges at eighteen percent (18\%) per annum on the unpaid balance (or the maximum rate allowed by law if such rate be less than 18\%). Customer shall be liable for all costs of collection, reasonable attorney's fees and court costs if DIALOG or Distributor shall find it necessary to collect delinquent payments and/or enforce any other rights or remedies available.

Other common obligations include statistical data on system use, the return of the products on a regular cycle, and a requirement to notify the licensor if the workstation is moved or the product is mounted on a different machine. Most libraries have no experience dealing with a licensor and an agreement that dictates how they operate. For instance, the UMI ProQuest license requires that:

Licensee will download the usage information to the tracking diskette and return the diskette to UMI with every Database update, not later than fifteen (15) days after Licensee receives an update, ... . 
The Reed Reference agreement provides an excellent example of a return of materials clause:

Superseded versions of the software program and database must be returned to Reed Reference Publishing within 10 days after updates are received. Failure to comply could result in suspension of update shipments.

\section{HOW WILL THE LICENSOR KNOW IF THE LIBRARY ABIDES BY THE TERMS OF THE AGREEMENT?}

For the most part, they won't know, but contractually they will have the right to know! Many licensors now include security and rights to audit clauses. The library is asked to take all reasonable and necessary action to limit and restrict use, control access, and protect and secure the product. The SilverPlatter Agreement provides a separate clause, identified in boldface, uppercase font, that discusses security and audit issues:

Customer hereby grants SilverPlatter the right to audit, during regular business hours, use of the Databases to ensure compliance with this Agreement, including without limitation, the number of simultaneous users permitted to access the Database. In a similar fashion, the DIALOG agreement states that:

A DIALOG employee, consultant, contractor, or distributor may visit your premises during your normal business hours to verify compliance with the LAN terms.

\section{WHAT DOES THIS MEAN TO THE LIBRARY?}

The simple days of copyright compliance have ended. Any library that wishes to provide access to electronic products must be prepared for massive change. From the selection decision through end-user training, electronic products require special consideration due to their license agreements, which are pervasive and unavoidable. They affect every aspect of the process.

\section{WHAT CAN BE DONE TO ASSURE WE DON'T SIGN AWAY OUR RIGHTS?}

While each library and most license agreements are unique, basic approaches to handling licenses can assure that users rights are not compromised. First, librarians must learn to read and understand the very fine print of license agreements. Only through detailed examination of the contractual commitments can the library be prepared to negotiate for its rights. Second, the library must define explicitly its user population, the product application and access, and intended use. Without this information, the licensor cannot modify the agreement to meet the library's needs. Third, librarians must continue to negotiate for license terms that provide sufficient rights to serve their users' needs [5]. Fourth, librarians must seek help with modifying or amending contracts. The licensor has used an attorney to draft the contract; why shouldn't the library use the services of legal counsel to respond? Finally, the library must assure compliance to the contract commitments and security for the products they acquire. Both the opportunity and the responsibility to take action to protect these rights belong to the library community.

\section{REFERENCES}

1. The five license agreements were titled as follows: UMI ProQuest subscription license; SilverPlatter Information subscription and license agreement; DIALOG OnDisc license 
agreement; Reed Reference Electronic Publishing limited user multiuser network software and database license agreement; and Chemical Abstracts Services CD-ROM license agreement. None had any other unique identifying codes or item numbers.

2. For an excellent discussion of current fair use interpretations, see Sinofsky, Esther R., $A$ Copyright Primer for Educational and Industrial Media Producers (Washington, DC: Association for Educational Communications and Technology, 1994), pp. 47-65.

3. Hemnes, Thomas M.S., and Alexander H. Pyle, A Guide to Copyright Issues in Higher Education. Washington, DC: National Association of College and University Attorneys, 1991, p, 2.

4. Franklin, Janice R., Database Ownership and Copyright Issues Among Automated Library Networks: An Analysis and Case Study. Norwood, NJ: Ablex Publishing Corp., 1993, p. 61.

5. Gasaway, Laura N., "Copyright in the Electronic Era," The Serials Librarian 24, 3/4 (1994), 153-162. 